\title{
Online Shop Sales Based on E-Commerce
}

\author{
G W Rahman ${ }^{1 *}$, S D Anggadini ${ }^{2}$ \\ \{ghifarywr27@mahasiswa.unikom.ac.id ${ }^{1}$, sridewianggadini@email.unikom.ac.id ${ }^{2}$ \} \\ Fakultas Ilmu Sosial dan Ilmu Politik, Universitas Komputer Indonesia, Indonesia ${ }^{1}$ \\ Departemen Akuntansi, Universitas Komputer Indonesia, Indonesia ${ }^{2}$
}

\begin{abstract}
The purpose of this research is to provide store sales businesses that are connected directly to websites with research information along with prices and purchasing methods. So that it can facilitate the purchase of products directly on the web. The method used in this research is a descriptive method, where the data obtained from this research comes from social media that can be used to facilitate this e-commerce business. The results of this study are expected to increase customer trust and loyalty towards existing ecommerce. With an e-commerce based business, it can be easier for sellers or customers to access faster in the process of buying and selling goods, besides that it can also simplify available information and improve the quality of services with internet use.
\end{abstract}

Keywords: E-commerce, online shop, service

\section{Introduction}

Nowadays, information has become an important part of the business world. Especially with the changing habits of shopping at the offline store, they prefer to shop through gadgets. The online shop recently is the world leader in buying and selling. Therefore, the online shop is one of the big economic drivers. Right, accurate, transparent, and clear information are several things that make people like to do online shopping.

In building an online business with other online businesses, the competition will make online businesses produce good quality and affordable products for the community [1]. According to Davis, Alanah, and Deepak Khazanchi, the ability to exchange opinions and the online experience are known as online word of mouth (WOM) and has been shown influence ecommerce sales. [2] According to Zeng, Daniel's social media refers to the mode of conversation, the spread of content creation, dissemination, and communication between communities. Unlike traditional media and broadcast-based industries, social media has damaged the boundaries between writers and readers, while the process of consumption and dissemination of information is intrinsically related to the process of generating and sharing information. [3] E-commerce is an economic transaction in which buyers and sellers gather through internet electronic media, make contractual agreements regarding the price and delivery of certain goods or services, and complete transactions through the delivery of payments and contracted goods or services (Guay \& Ettwein, 1998, Zwaa, 1996). [4] According to Philip Kotler and Kevin Keller Social Media is a means for consumers to share text, image, video and audio information and with companies and vice versa. Social media is an online media with its users able to easily participate, share and create content including blogs, social networks, wikis, forums, and virtual worlds. Social media itself can have a positive or negative function, depending on its use. [5] According to Dr. Ir Eddy Soeryanto Soegoto said that e-commerce 
sites need careful attention to structure, design and fill their content to be successful. [6] Online business via the Internet is a promising business considering that the market is an Internet user spread throughout the world. However, in practice, many obstacles hamper the development of online businesses. First, security issues in conducting online transactions (Situmorang, James Rianto, 2012). [7] According to Kietzmann, Jan H. The phenomenon of social media, which can now significantly affect the reputation, sales, and even the resilience of the company. However, many executives stay away from or ignore this form of media because they do not understand what it is, the various forms that can be taken, and how to be involved in learning because different social media activities are determined by the extent to which they focus on just a few. The internet is increasingly becoming a part of everyday life by facilitating networking opportunities and offering ways to get along with others who share the same interests, values, or goals $[8,9,10]$.

This study aims to explain how the opportunities to sell e-commerce-based online stores can compete with the market. Besides, using websites and social media can have a positive impact on entrepreneurs to sell their products to consumers. While the method in this study used descriptive analysis method, in which the data from this study is obtained from social media and website which has been one of the facilitators of this e-commerce business.

\section{Method}

This study used a descriptive method which describes how an online shop entrepreneur sells or markets their products to be sold to consumers through electronic systems in the form of internet, websites, and social media. The social media used in this study is Instagram, while the website directly uses the online shop website to be analyzed, namely Ouval Research or $\mathrm{RSCH}$.

\section{Result and Discussion}

Electronic commerce is the distribution, purchase, sale, marketing of goods and services through electronic systems such as the internet or television, www, or other computer networks. E-Commerce can involve electronic fund transfers, electronic data exchanges, automated inventory management systems, and automated data collection systems [11, 12]. The sale of this online store wants to make it easier for consumers or customers to shop easily through websites and social media so that consumers no longer need to come far to the store to buy products. But there is a website that has been provided and social media makes it easy for payments and purchases desired by consumers when buying products.

Ouval Research or RSCH is one product that sells goods and services. This shop sells various clothes. The products offered are no less competitive with other competitors they prioritize product quality and strengthen the brand to maintain customer loyalty. This store located in Bandung. This store has opened a branch in the Bandung area. This shop has a different design from other clothes and has its characteristics, using Swiss design typography. (Figure 1) tells One of the online sales through the website. 


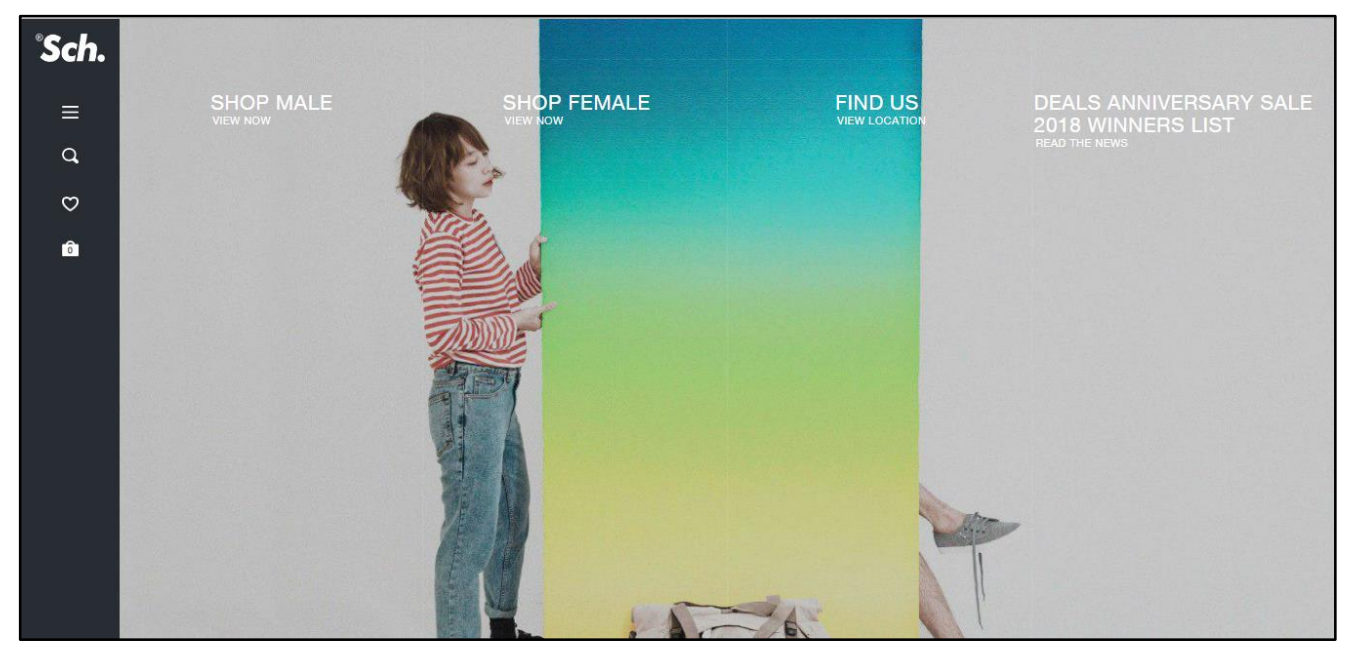

Fig 1. Main Menu. The figure was adapted from schofficial.com/ on July $5^{\text {th }}, 2018$.

One of the promotions that can be accessed by people who want to buy goods and get information on the sale of this website. We can see in the picture shown how consumers when visiting a website from Research online shop, consumers can easily search for products that they want to buy, for example, if consumers want to buy products for men, there is already a male shop and when a woman wants to buy a product, a female shop is listed. Thus consumers can easily when they want to find the criteria for the product they want to buy. (Figure 2) shows services offered.

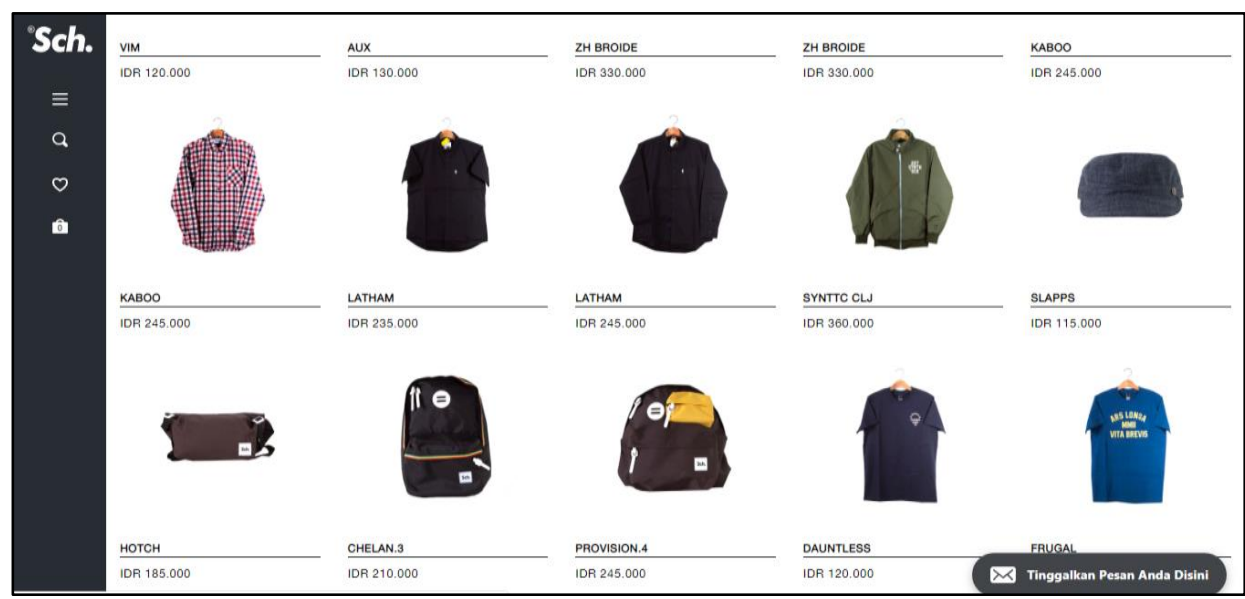

Fig 2. Services offered. Main Menu. Figure was adapted from schofficial.com/ on July $5^{\text {th }}, 2018$.

One of the services provided by this online sale is selling one of the products offered in the form of products such as shirts, hoodies, bags and t-shirts for men. And the pictures we can see are also prices that can facilitate consumers when they want to buy the product. (Figure 3) shows main menu of the account 


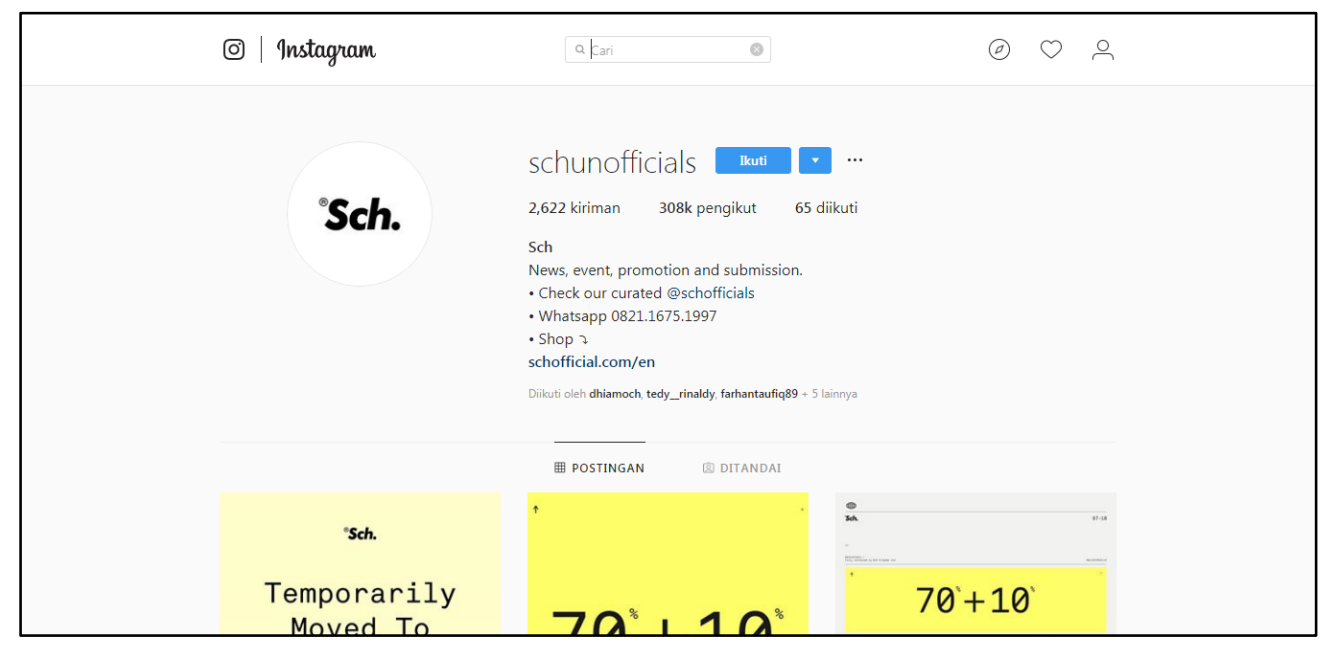

Fig 3. Instagram $R \boldsymbol{S C H}$. Main Menu. The figure was adapted from instagram.com/ on July $6^{\text {th }}, 2018$.

On social media, one of them is Instagram. On Instagram, we can order or buy products that we want, and the use is the same as the website. Consumers are facilitated in buying products.

\section{Conclusion}

Continuous innovation is the best way to compete in a marketplace that continues to move. Every new technology needs to be assessed, analyzed, tested and applied quickly. The development of innovations supported by adaptive abilities will promise long-term success. Therefore, competition in the digital era is so tight, so that for the sale of online stores must be stronger in marketing their products and high loyalty to consumers must be maintained so that consumers can feel the quality that is given. Characteristics must also be maintained, if the characteristics have been lost then consumers will no longer trust the quality that exists and can have a bad impact on the owner of the online store itself.

\section{References}

[1] Soeryanto Soegoto, Eddy. Entrepreneurship Menjadi Pembisnis Ulung. Cet. Kedua, Edisi Revisi. Jakarta. Penerbit Gramedia. 2014.

[2] Davis, Alanah, and Deepak Khazanchi.:An empirical study of online word of mouth as a predictor for multi-product category e-commerce sales. Electronic markets 18.2. 130-141. (2008).

[3] Zeng, Daniel, et al.: Social media analytics and intelligence. IEEE Intelligent Systems 25.6: 13-16. (2010).

[4] Kevin Lane Keller.: Twenty-First Century Branding. (1997).

[5] Kietzmann, Jan H., et al.: Social media? Get serious! Understanding the functional building blocks of social media. Business horizons 54.3. 241-251. (2011).

[6] Guay, D., \& Ettwein, J.: Internet Commerce Basics. Electronic Markets 8 (1), 12-15

[7] Giordano, Carolyn, and Christine Giordano. Health professions students' use of social media. Journal of allied health 40.2 (2011): 78-81. (1998). 
[8] Soegoto, E. S., Juliana, R., \& Oktafiani, D.: Designing Consultant Services Sales System through Online Store. In IOP Conference Series: Materials Science and Engineering (Vol. 407, No. 1, p. 012027).

[9] Soegoto, E. S., Christiani, A., \& Oktafiani, D.: Development of E-Commerce Technology in World of Online Business. In IOP Conference Series: Materials Science and Engineering (Vol. 407, No. 1, p. 012031).

[10] Soegoto, E. S., \& Purwandani, F. A.: Application of IT-Based Web on Online store. In IOP Conference Series: Materials Science and Engineering (Vol. 407, No. 1, p. 012041).

[11] Nanehkaran, Y. A.: An introduction to electronic commerce. International journal of scientific \& technology research, 2(4), 190-193. (2013).

[12] Journal of BrandKevin Lane Keller and Philip Kotler.: Holistic Marketing: A Broad. (2006). 